\title{
CORPORATE GOVERNANCE IN SPANISH SAVINGS BANKS. ITS RELATIONSHIP WITH FINANCIAL AND SOCIAL PERFORMANCE
}

\begin{abstract}
Purpose This paper presents empirical evidence about relationships between the corporate governance mechanisms of the Spanish savings banks, their financial and social performance and their profitability prior to their collapse.

Design We use a structural equation model (SEM), taking the return on assets as the dependent variable, and corporate governance, corporate social responsibility and efficiency as explanatory constructs. SEM methodology provides interesting features which allows a better definition of some organisational characteristics.
\end{abstract}

Findings Results indicate that corporate governance characteristics, including the politicisation of governance bodies, did not affect financial performance. The size of the board of directors had a significant influence on social responsibility. In addition, results suggest that the whole board focused on social issues, whereas non-executive members were less concerned about economic issues. Greater money allocation to social welfare programmes resulted in higher profitability, which can be explained by competitive advantages, reputation and customer satisfaction.

Social implications Nowadays, some political parties demand either for the creation of a public banking sector or banks with social goals. This paper provides interesting insights to the debate.

Originality/value The influence of personal attributes of board members on performance need to be analysed in greater depth in the non-profit sector. The SEM methodology allows us to include some board attributes and performance dimensions in a better way than with other methodologies.

Keywords: non-profit banks, corporate governance, structural equation model, Spain Article Classification: Research paper 


\section{CORPORATE GOVERNANCE IN SPANISH SAVINGS BANKS. ITS RELATIONSHIP WITH FINANCIAL AND SOCIAL PERFORMANCE}

\section{Introduction}

During the financial crisis at the end of the 2000s, the Spanish banking system almost collapsed and most of the Spanish banks needed economic help to overcome the crisis. Commercial banks were able to find financial support from their shareholders by increasing capital. However, most of the Spanish savings banks (SBs) which, prior to the crisis, made up approximately $50 \%$ of the Spanish banking system, had to be rescued by the Government. SBs were private foundations that had two main objectives: financial and social. As these entities did not operate under capital market discipline, they showed shortages in competitiveness and efficiency (Crespí et al., 2004).

Most research on the effect of corporate governance (CG) does not take into account how the governance mechanisms and social responsibility practices affect firm performance (Fernández-Gago et al., 2016). Considering that SBs had two organisational goals namely financial and social, the study the influence of CG on performance in these entities is biased and incomplete if these two dimensions are not included in the study as dependent and interrelated variables. Furthermore, tensions between philanthropic and business oriented goals can arise in entities, like SBs, with social and economic objectives.

The academic literature has studied formal, rather than qualitative, measures of boardroom composition (e.g. board size, independence, ownership) and their effect on banking performance, but few papers have analysed the influence of political presence on these boards (García-Meca and García-García, 2015). The political presence in the governance of Spanish SBs makes the Spanish financial crisis different to those of other countries (Fonseca, 2005; Delgado et al., 2007; Pina et al., 2016). Political influence 
and the absence of owners were considered major problems of SBs and causes of their collapse. Thus, in the study of CG mechanisms of the SBs, as well as in any foundation, or non-government entity, with a strong political influence, the study of the effects of political presence on boards is needed.

Previous empirical research has mainly analysed Spanish SBs only from economic or financial points of view: productivity (Buch et al., 2011; Grifell-Tatje and Lovell 1996; Illueca et al., 2009; La Porta et al., 2002; Serrano-Cinca et al., 2004; TortosaAusina et al., 2008), costs (Carbo et al., 2003; Maudos et al., 2002a; Prior, 2003) or efficiency (Cuesta and Orea, 2002; García-Cestona and Surroca, 2008 and TortosaAusina, 2002; Prior et al., 2016). However, as one of the two goals of these entities is the funding of social welfare programmes, an economic approach to their performance is both limited and biased. Thus, an approach that considers the achievement of social welfare goals is needed.

The objective of this paper is twofold. First, it studies the effect of political presence on the boards on organisational performance. This qualitative characteristic of the board is considered a key factor in the failure of the SBs. Second, it analyses their performance multidimensionally because these entities had both financial and social goals. The paper analyses the performance of the SBs from two dimensions: the financial and the social performance. The relationship between corporate governance and financial and social performance has been hardly studied with these two performance dimensions as interrelated and dependent variables. This is the gap that we are trying to fill with our paper. In a period when some political parties demand either for the creation of a public banking sector or banks with social goals, new analyses of the performance of SBs which, given the political control of their boards can be considered similar to government banks, can provide interesting insights to the debate. 
The article is organised as follows. The next section presents the SBs. Section 3 develops our hypotheses. Section 4 details or research design, including the methodology employed, a structural equation model, data and the variables used in the analysis. In Section 5, we present the empirical results. Sections 6 and 7 contain the discussion and conclusions.

\section{The Spanish Saving Banks context}

SBs were private foundations that had two main objectives: financial and social. The term 'financial objectives' refers to the traditional business of the banking sector, that is, granting credit and capturing deposits. Their social function required that part of their profits, the so-called 'social dividends', be allocated in their region of origin through the delivery of cultural, charitable and social services to the population. The social nature of these entities was reflected in their corporate governance structure, which was based on two main bodies: the General Assembly and the Board of Directors. The General Assembly was the highest governing body, elected the Board of Directors and represented the main stakeholders, namely, depositors, regional and local governments, founders and employees. The General Assembly was the body which approved the amount devoted to social activities. 'Social objectives' differentiated SBs from other financial institutions. Through 'social dividends', SBs returned part of their profits to society by funding charitable and cultural activities.

SBs offered the same financial services as commercial banks. SBs did not have shareholders, and were, in fact, managed and controlled by political institutions, mainly regional and local governments. During many years, these entities were acclaimed as an example of excellent management. Clearly, the financial crisis has shown these entities failed in terms of the risks they assumed. The need for public funds to rescue some SBs 
during the last financial crisis was a controversial issue, particularly when the commercial banks did not get public money. However, from their very origins, SBs dedicated millions of euros as profit distribution and social expenditure to fund cultural, social, health and other welfare projects.

Most of the Spanish SBs were created at the end of the $19^{\text {th }}$ Century by civil and catholic associations. They were private foundations with financial and social objectives (social welfare). With the arrival of democracy in Spain in 1978, the SBs strengthened their market position and a national law put them on the same level as private banks. Until 1989, the SBs only operated in one region and they were not allowed to operate in other territories. Although they were financial entities with commercial goals, local and regional governments exerted their control by having voting rights on the General Assembly.

At the end of the 1980s, Spanish SBs underwent a transformation process. National legislation extended their sphere of operations from a regional to a national level, which allowed them to open branches outside their region. Most SBs expanded and diversified their territorial branching network (Illueca et al., 2009). This expansion played an important role in the increase of competition in the banking sector and led to aggressive marketing policies to obtain more market share. According to Pastor et al. (2016), far from generating positive effects through greater competition in the banking sector, the diversification of investments and the reduction of risk controls resulted in lower productivity and worse resource allocation.

\section{Hypotheses}

In this section, we analyse the factors that contribute to explaining the performance of savings banks and develop our hypotheses. CSR is a broad concept 
which encompasses different dimensions, such as social and environmental performance. Our measure of social performance focuses on the way organisational achievements are given back to society and stakeholders. We focus our analyses on social performance although we base our development hypotheses on the literature about CSR because of the lack of empirical research about the relationship between corporate governance and social performance.

The governing bodies of the SBs represented the interests of the different stakeholders. The stewardship theory proposes that stewards, in our case board members, are motivated to act in the best interests of their principals and make decisions that are in the best interests of the overall organisation in cases where different stakeholders express competing objectives (Davis et al., 1997). For non-profit entities, legitimacy can be as important as achieving their goals. Organisational legitimacy is achieved when actions are observed to be desirable, or appropriate, within the socially constructed system of norms, values, beliefs and definitions (Schuman, 1995). The legitimacy theory assumes that it is important for an organisation to engage in and control the processes of legitimization in order to demonstrate its congruence with societal values (Guthrie and Parker, 1989). Thus, legitimacy is important to ensure continued support from society (Laguir et al, 2015).

\subsection{Influence of the General Assembly on performance}

The General Assembly set the priorities that SBs assigned to their different objectives. This body acted in a similar way to the shareholders' annual general meeting and selected the board of directors and decided the allocation of profits. Its structure, where different stakeholders were represented, conditioned its strategy and main decisions. Spanish studies that demonstrate the relevance of this governing body are 
those of Delgado et al., (2007), García-Meca and Sánchez-Ballesta (2014) and GarcíaMeca and García-García (2015). This assembly represented different stakeholders, so it is logical to assume that its members acted as stewards of the social group they represented on the assembly. It is expected that the General Assembly influenced the financial and social performance of SBs, depending on the objectives of the groups represented, with a greater focus on one dimension of the other depending on the need of its member for legitimacy. Therefore, we test the following hypothesis:

H1: The General Assembly influenced efficiency and social welfare programmes.

\subsection{Influence of political presence on the board on performance}

Political presence in the governance of Spanish SBs made the Spanish financial crisis different to those of other countries (Crespí et al., 2004; Delgado et al., 2007; Fonseca, 2005). The politicisation of the governing bodies of SBs led to a lower performance (García-Cestona and Surroca, 2008) and, when public authorities had a higher participation in SBs, the level of risk increased as investments responded to political objectives rather than to economic goals (Pina et al., 2016). Furthermore, a systematic exchange of favours between politicians and business elites arose (GarcíaMeca, 2015). The study of García-Meca and García-García (2015) shows that higher political influence on boards resulted in lower efficiency.

Besides politicisation, there were concerns about the inexperience and lack of qualifications of the members of the governing bodies of SBs. Political presence allowed managers without economic or financial education to participate in the running of SBs (Pina et al., 2016). In the banking industry, professionalism is even more important than in other companies due to the complex aspects of the business. The Spanish reform of the SBs law sought the professionalisation of their governing bodies. 
According to Cunat and Garicano (2010), a SB run by someone with post-graduate education, with previous banking experience and with no previous political appointments was likely to have significantly less real estate lending as a share of total lending and a lower rate of non-performing loans. García-Meca and Sánchez-Ballesta (2014) conclude that SBs run by a chairman with previous banking experience were likely to be significantly more solvent. In sum, board members with financial expertise improve the corporate governance by enhancing the decision-making process. Therefore, the presence of more politicians is likely to reduce the influence of professional managers on decisions about financial issues. Menozzi et al. (2012) for Stated-Owned enterprises find that more politised boards exert a positive effect on social performance, measured in increasing the number of employees and favouring contracting staff, but a negative effect on the financial performance. In line with the stewardship theory, boards are more likely to have a greater focus on social goals than on financial goals because the former were more important for a majority of the stakeholders. In terms of the stewardship and legitimacy theories, politicians on boards will most likely be focused on the social dimension of performance than on the economic one to better serve the interest of main stakeholders and to gain legitimacy in the opinion of the citizenry that they represent.

Therefore, we test the following hypotheses:

H2a: A more politicised board is negatively related to efficiency in the Spanish savings banks sector.

H2b: A more politicised board is positively related to social welfare programmes in the Spanish savings banks sector. 


\subsection{Influence of board size on performance}

Another board characteristic included in corporate governance studies is size (see e.g. Bozec and Dia, 2007; Bennedsen et al., 2008; Eisenberg et al., 1998; Coles et al., 2008; Cheng, 2008; Guest, 2009; Adams and Mehran, 2012). There are two main views in the literature regarding the influence of board size on firm performance (see e.g. Guest, 2009). On the one hand, larger boards positively affect firm performance because they possess greater collective information and are more likely to have more independent directors who can provide better monitoring. For the banking industry, the results of Adams and Mehran (2012) support this view. On the other hand, larger boards may have problems of coordination and communication; reaching consensus may be more difficult. The possibility of the presence of free-riding directors is also higher because the cost to any individual director of not exercising diligence falls in proportion to board size. De Andres and Vallelado (2008) find that the addition of new directors is positively related to performance, but there is a point after which adding new directors reduces bank value. A significant part of the empirical literature agrees that, after reaching a certain size, adding new directors to the board negatively influences financial performance and/or the value of the firm (e.g. Yermack, 1996; Eisenberg et al., 1998, De Andres et al., 2005). Bennedsen et al. (2008) explain their results arguing that the 'right' number of directors is a trade-off between the benefits of having sufficient competencies represented and the cost of having free-riders among the directors. Nonetheless, the results of Coles et al. (2008) support a third view which states that very small or very large boards are optimal in terms of firm value.

Regarding the influence of board size on social performance, and, in particular, firm allocation to philanthropic practices, Brown et al. (2006) suggest that larger boards tend to become symbolic and a source of social interaction for the directors, and lose 
contact with the managerial process. The results of Brown et al. (2006) show that firms with larger boards give significantly more cash to charity. These factors may lead to a lower financial performance orientation and a greater social orientation of the board. These authors give two main reasons for a positive relationship between board size and donations. First, larger boards are more likely to have a less effective monitoring, leading to larger philanthropic contributions. Second, the larger the board, the more directors are likely to pursue for their own social interests, also leading to larger money contributions. Cuadrado-Ballesteros et al. (2015) find a positive association between board size and CSR practices although, when this association surpasses a threshold, CSR practices are reduced. Bai (2013), for board attributes in non-profit organisations (US hospitals), find that whereas board size is negatively associated to social performance in for-profit hospitals, it is positively associated to social performance in non-profit hospitals. Menozzi et al. (2012) find that board size has a positive effect on social performance but a negative one on financial performance.

In terms of the stewardship and legitimacy theories, larger boards will most likely have a more diverse presence of stakeholders for whom the social dimension of performance is more important than the economic one. To better represent the interests of stakeholders, and to gain legitimacy, larger boards will be more socially than economically oriented. Therefore, we test the following hypotheses:

H3a: A larger board is negatively related to efficiency in the Spanish savings banks sector.

H3b: A larger board is positively related to social welfare programmes in the Spanish savings banks sector. 


\subsection{The efficiency factor in the savings bank sector}

The process of financial integration and the structural change in the Spanish banking sector during the 1990s sought to promote competition (Cuesta and Orea, 2002) with the purpose of improving the efficiency of the sector. This competition was the result of a liberalised regulatory framework, the emergence of new financial intermediaries, the process of disintermediation and the diffusion of new technologies. Salas and Saurina (2003) assert that, in a more concentrated market, consolidated banks will adopt less risky policies. An increase in banking competition generates more efficiency (Reboredo, 2004) and enhances the performance of the entities in this sector (Maudos et al., 2002b; Prior, 2003), mainly because cost reductions arising from technical efficiency have a positive influence on profits. An efficient company that reduces costs has more ability to meet its long-term costs and to accomplish long-term expansion and growth.

SBs were non-profit organisations but, as commercial financial entities, they competed with the other banks in the financial market and had to obtain profits to maintain their market share. The 'corporatisation' of these entities meant changes in their governance to imitate commercial banks' management and to be more efficient. Entities that carry out a restructuring strategy that includes the reduction of operating expenses such as salaries, central services expenses and number of branches will be more efficient. When an entity decreases staff costs and makes labour force adjustments obtains a higher efficiency and all these initiatives lead to more profitability.

However, entities may be profitable without being efficient. SBs granted a great quantity of credits and obtained large profits, but large profits are not necessarily the result of acting efficiently. Furthermore, despite the high competition, SBs had a significant market share in their region of origin, which allowed them to apply higher 
fees, which might compensate for these inefficiencies. As these entities did not operate under capital market discipline, the relationship between efficiency and profitability is not clear. Politicians sought a greater implication of savings banks in regional development (García-Cestona and Surroca, 2008) and the financing of projects according to political criteria rather than to profitability. The political presence on the governing bodies interferes in the relationship between efficiency and profitability. So, our fourth hypothesis is:

H4: Efficiency is related to the financial performance of the Spanish savings banks.

\subsection{The social welfare programmes in the savings bank sector}

The goal of the contribution of the SBs to wealth distribution and welfare was to invest in social or community programs and to promote regional development when the private sector lacked interest in these investments (García-Cestona and Surroca, 2008). Key regional development projects were carried out with financial support from the SBs (Maroto and Melle, 1999; Fonseca, 2005). 88\% of SBs had collaboration agreements with the public sector regarding welfare services, and SBs devoted almost 3,000 million euros to social programs in 2009. The expenditure was focused on social welfare and healthcare $(41 \%)$, culture and leisure activities $(33 \%)$, education and research $(17 \%)$, and historic and natural heritage (9\%) (CECA, 2009). However, its contribution to the sustainable enlargement of society was questioned because of its lack of economic viability (Carbo et al., 2003; San-Jose et al., 2014). The lack of ownership and the political influence on savings banks' boards affected managerial decisions because politicians sought to finance projects according to political criteria rather than to profitability. Huge investments in public projects, such as airports, high speed train 
stations, conference centres and motorways which had not activity, together with risky loans, generated the bankruptcy of the savings banks sector and the banking rescue process in Spain (Pina et al. 2016).

Social objectives can have negative effects, such as underperformance and inefficient credit allocation because of political influence and agency problems for SBs (e.g., Shleifer and Vishny, 1994; La Porta et al., 2002; Sapienza, 2002; Illueca et al., 2013). As Illueca et al. (2009) assert, the 'social dividends' reflect the non-profit nature of SBs, which may often conflict with value maximisation goals. In line with this, Fernández-Gago et al. (2016) consider that the managers of a firm with good performance might reduce social activities to maximise their own personal income in the short term and that, if the financial performance is low, the managers might try to justify this poor performance by carrying out attractive social programmes. However, in the academic literature, other authors have found that there is no direct relationship between CSR and financial performance (Surroca et al., 2004; Garcia-Castro et al, 2010) or that there is a positive effect of CSR on firm performance, due to its effect on competitive advantages, reputation and customer satisfaction (Saeidi et al., 2015). Rodgers et al. (2013) find that firms' broad societal strategies can lead to a material improvement in their financial performance and enhance their market value.

So, our last hypothesis is:

H5: Resource allocation to social welfare programmes affects the financial performance of Spanish savings banks. 


\section{Methodology and research design}

\subsection{Methodology and sample}

We use the structural equation modelling (SEM) based on partial least squares (PLS) approach (SmartPLS 2.0 software) for our analyses. This technique has been widely used in marketing (Roldán and Sánchez-Franco, 2012). SEM is a family of statistical techniques that incorporates and integrates path analysis and factor analysis. The SEM process consists of two steps: validating the measurement model and fitting the structural model. Serrano-Cinca et al. (2007) used this methodology to predict bank bankruptcy. Sarstedt et al. (2014) explain different characteristics and advantages of the PLS-SEM methodology and use it in a family business analysis. Another example of the use of SEM, although with a different approach, is the work of Shaukat et al. (2016), studying the relationship between board attributes and CSR performance.

One of the main advantages of the SEM-PLS technique is that it allows us to carry out analyses which include financial and social performance in the same model to study the effect of corporate governance on these two potentially interrelated dimensions. Most of the literature uses OLS-based methodologies in which several independent variables explain just one performance dimension (dependent variable). SEM allows the study of interactions between variables (or constructs), that is, a variable can be both a dependent and an independent variable of other variables. Therefore, complex relationships between variables with direct and indirect effects can be studied (Serrano-Cinca et al., 2007). Another advantage of this methodology is that it can use 'constructs' as variables. Constructs are made up of several items or indicators to better capture the characteristics and features of the complex 'reality' to be studied, strengthening the results and their interpretation. While other approaches to SEM (such 
as covariance-based methods) have strong sample-size requirements, PLS restrictions are generally much smaller. Despite the growing use of the SEM methodology in business research, studies applying PLS-SEM in the management and finance areas are relatively scarce. One limitation of this methodology is that, because PLS is a regression based technique, the number of variables/constructs in the model is limited by the size of the sample. The minimum sample size should be, at least, ten times the number of arrows pointing to a variable/construct (Hair et al, 2012). Another limitation highlighted by these authors is that PLS-SEM is a more prediction-oriented approach compared to other SEM methodologies such as covariance based (CB) methods, which have a confirmatory approach.

For our analyses, we develop a SEM-PLS model to test the effect of corporate bodies on social responsibility and efficiency, assuming that these two firm performance dimensions influence profitability. Most of the academic literature focuses on the influence of board characteristics on one outcome dimension, namely economic performance or environmental or social responsibility. This approach does not take into consideration the interrelation between these dimensions. CSR is a multidimensional concept which encompasses social, governance, economic and environmental dimensions (Laguir et al 2015).

The SEM-PLS methodology allows us to include several relationships which result in a better decomposition of how the variables/constructs included in the model interact. We contribute to the scarce, but growing, literature that studies corporate governance considering the multidimensional performance of firms and non-profit entities. SEM allows us to test all of the relationships in the model simultaneously and PLS is particularly appropriate when the model is complex (Fornell and Bookstein, 1982). Garcia-Torea et al (2016) use the SEM methodology 
to determine whether economic and social responsible approaches are possible when boards are properly focused on these two dimensions. Their results show that effective boards, that is, boards that fulfil several characteristics such as an adequate size, independence or diversity, are able of protecting shareholder value and also respond to the interests of the rest of the firm's stakeholders.

Shaukat et al (2016) test the link between the CSR attributes of the board, its CSR strategy, and its environmental and social performance. They also use a SEM approach and find that the greater the CSR orientation of the board, the more proactive and comprehensive the firm's CSR strategy and the higher its environmental and social performance. The CSR orientation of the board is measured by the board's independence, its gender diversity, and the financial expertise of the audit committee. Park et al (2017) demonstrate that a company's CSR commitment induces greater satisfaction with and trust in the company and its services, which encourage consumers to remain loyal. Greater loyalty will most likely be reflected in the economic results of companies and a better brand image. Engagement in CSR and brand management helps to maximize firm value (Wang et al, 2015). A greater social orientation increases profitability due to competitive advantages, reputation and customer satisfaction (Saeidi et al. 2015). Rodgers et al (2013) analyse whether a firm's investment in CSR pays off economically in the long term and find that the customer dimension of CSR has a significant impact on financial performance measures.

We base the use of a SEM-PLS approach on the premise that boards do not take economic and CSR decisions independently and that these decisions together influence the final financial return of organisations. Moreover, for non-profit 
entities, CSR and economic decisions must go hand in hand and this combination is reflected in their profitability.

This study is focused on the 45 SBs that were operating in Spain in 2009. After 2009, the savings banks were involved in merging processes. Most of the 45 savings banks have finally merged into 5 big banks. We collected our data from three different sources: financial information of SBs was obtained from the CECA (Spanish Confederation of Savings Banks), whereas corporate governance information of SBs regarding board and power distribution was taken from the Comisión Nacional del Mercado de Valores-Spanish Securities Market Commission. This study analyses factors that influence SBs profitability using a structural equation model and taking the main governing bodies, efficiency and social welfare as explanatory factors.

\subsection{Variable measurement and model}

Our model captures two key features of the governing bodies of SBs, namely, size and politicisation. Size is almost always included in academic studies as a key feature of boards of directors. Having more members in a corporate body increases its diversity of skills and its representativeness. In a democratic society, politicians and elected governments represent society. Politicisation also captures the dependence of members towards elected governments. In the elusive concept of the property of the SBs, Spanish law gave local and regional government a great influence in the selection of the members of their governing bodies

To assess the effect of the General Assembly, two variables have been included: the size of the General Assembly and its power distribution. Size is measured as the number of members in the General Assembly (GAsize). We determine the distribution of power in the General Assembly by calculating the percentage of members who 
represent local and regional governments over the total number of members (GApolit). The General Assembly is the body that, at least nominally, decided the SB strategy and set its goals.

To analyse the board, one variable indicative of size and one construct associated the politicisation have been included. The number of members in the board is indicative of their size and denoted as BDsize. The politicisation of the board (BDpolit) is captured by a construct made up of two items: the percentage of members of the board representing a regional or local government over the total number of members (POL) and a dummy variable (CEO) representing the political connections or links of the CEO to a political party. This variable takes the value ' 0 ' when the CEO has no political connections and ' 1 ' otherwise. The importance of key members in board decisions is supported by the Upper Echelon Theory (see Hambrick and Mason, 1984) which states that organisational outcomes reflect the values and cognitive bases of powerful actors in the organisation. For example, Ellwood and Garcia-Lacalle (2015) show the importance of personal attributes (gender) of the chairperson and the CEO on the performance of non-profit organisations. As stated, the use of a construct for capturing the politicisation of the board allows us to include in a better way this personal attribute of the members of the board, which has been less frequently studied than other attributes. This way, we can better measure its influence on the performance dimensions included in our study.

SBs are non-profit organisations and, because of this, they are under less pressure to obtain profits than commercial banks. So, the traditional assessment methods (profitability indicators) are not enough to analyse these entities. Therefore, to study SB performance we assess their efficiency and their social responsibility. 
There are two main alternatives to measure banking activity, namely, the production approach and the intermediation approach. The first considers banking institutions as producers of services for their clients. The intermediation approach expands the definition of inputs to include deposits. It considers banking institutions primarily as intermediating entities between savers and investors. Prior studies have measured performance by focusing on one of these two alternatives, particularly the intermediation approach (Illueca et al., 2009) but, there is, as far as we know, no research that considers both approaches. In this study, we adopt this dual perspective. To measure SBs efficiency, we use a construct made up of two scores: DEA1, with an intermediation approach and DEA2, with a production approach, obtained by applying Data Envelopment Analysis (DEA) developed by Charnes et al. (1978) and Banker (1984).

For the intermediation approach (DEA1), the amount of deposits, their cost measured as interest and charges paid and the cost of the staff have been included as inputs in the model. As outputs, we include loans and interest and fees received. All these variables are relevant because they reflect the view that SBs make loans to obtain an income (Kumbhakar et al. 2001). The intermediation approach with these inputs and outputs has been used by Maudos et al. (2002a), Carbo et al. (2003), Cuesta and Zofío (2005), Tortosa-Ausina et al. (2008), Illueca et al. (2009) and Williams et al. (2011), among others. For the production approach (DEA2), the number of branches and the staff have been included as inputs in the model. As outputs, we include the amount of deposits and loans.

Social responsibility is assessed using the construct 'social responsibility', which is made up of two indicators: euros effectively devoted to social welfare in 2009 (SR1) and the part of the profits of 2008 approved by the General Assembly to be allocated to 
social welfare (SR2). Both variables are introduced into the model in their natural logarithms.

Financial performance is a complex concept, so we include ratios related to a single aspect of financial performance: profitability. Previous empirical studies (Lozano Vivas, 1997; Berger and Mester, 1997; Maudos et al., 2002a; Sapienza, 2002; Illueca et al., 2013; Trujillo-Ponce, 2013; García-Meca and García-García, 2015; among others) have included Return on Assets (ROA) and/or Return on Equity (ROE) to study bank profitability. The return on assets (ROA) is perhaps the single most important ratio for comparing the efficiency and operational performance of banks (Trujillo, 2013). Other papers that have used this magnitude in this context are Akhavein et al. (1997), Sapienza (2002), Vander-Vennet (2006), Andres and Vallelado (2008), Vallascas and Hagendorff (2011), Caiazza et al. (2013), Behr and Heid (2011) and Pina et al. (2017). In addition, the level of bank capital funds is subject to capital adequacy standards (Vander Vennet, 1996) and SBs were foundations, that is, they did not have equity instruments so they did not have shares and, hence, shareholders and owners. We create the construct "financial performance" with two financial ratios associated with ROA: Profit before Tax/Assets (ROA1), and Net Profit/Assets (ROA2).

\section{Control variable}

The size of the entity is a characteristic which is usually included in any analysis of the topic and contributes to explaining the variation of the performance of the SBs (e.g. Maudos et al., 2002; Carbo et al., 2003; de Andres and Vallelado, 2008). The literature normally uses one single indicator to capture the size of the entity but, in fact, size is a characteristic that can be measured in different ways. Using SEM advantages, we capture the size of the SBs using three measures: the total assets (Assets), number of employees (Staff), and number of branches (Branches) of each Spanish SB in 2009. 
These variables are transformed into their logarithmic form in order to minimise normality problems and to avoid heteroscedasticity.

\section{Model explanation}

Figure 1 shows the model that analyses the relationships and hypotheses to be tested. Circular variables represent "constructs" made up of two items while squares represent variables made up of a single item. Our model takes advantage of the SEMPLS methodology in the following way. First, key variables are included as constructs instead of single-item variables. The politicisation of the board, the focus of our study about this corporate body, takes into account both the percentage of politicians on the board and whether the CEO, a key influential seat, also had political links. The 'dependent' variables, efficiency, social responsibility and profitability are also constructs. Constructs capture the variables included in a model better. Second, corporate bodies do not take decisions about one performance dimension without considering the other dimensions. Thus, the inclusion of two performance dimensions in the model captures the influence of governing bodies on them better. Third, boards take economic and social decisions which influence the profitability of the SBs. The inclusion of profitability in the model as a 'truly' dependent variable closes the relationship between the governing bodies, performance dimensions and profitability. Size is included as a control variable. As a limitation of the model, due to sample size, only two board features have been analysed. In addition, it is worth remembering that CSR is a multidimensional concept. Although the environmental dimension is not included in our model, SBs do not carry out activities that are especially harmful to the environment. Table 1 presents the description and items include in our variables. 
[Insert Figure 1 about here]

[Insert Table 1 about here]

\section{Analysis of results}

PLS analysis must be developed in two independent stages: the measurement model analysis and the structural model analysis. The measurement model assessment involves the examination of the adequacy of the measurement scales. The analysis of the structural model focuses on testing the causal paths between the constructs that compose the theoretical model. This procedure guarantees the reliability and validity of the measurement instruments. The examination of the structural model focuses on testing the causal paths between the constructs that compose the theoretical model. Table 2 shows the descriptive statistics of the variables included in the analyses.

[Insert Table 2 about here]

As shown in Table 2, the percentage of representatives of regional and local governments in the General Assembly ranges from $16 \%$ to $50 \%$, which shows the diversity of the SBs of the sample. This diversity is more pronounced in the Boards, with a range of $5 \%$ to $74 \%$ and a mean of $36 \%$, which shows that political institutions had significant participations, in general, in the decision-making process. As for the size of governing bodies, the table shows the high diversity in the sample and the freedom of SBs to decide the number of members of both bodies. The mean of the members on the board is 18 , which is higher than that of the boards of the Spanish commercial banks studied by De Andres and Vallelado (2008), which was 14. Table 2 shows that almost 
half of the sample (19 out of 45) has a political connected CEO. The mean of the efficiency, measured by DEA1 and DEA2, is $93 \%$ and $81 \%$, respectively, which are high scores. The profit and expenses devoted to social welfare is high, with SBs devoting, on average, 70 million euros to social programmes. However, some SBs devoted very little to their social programmes. The two variables indicative of ROA have similar descriptive statistics and, although some SBs present negative values, they do not reach such extreme values as those reported by De Andres and Vallelado (2008), which were $-9 \%$ and $7 \%$.

\subsection{Analysis of the measurement model}

We estimate the measurement model with PLS in order to analyse internal consistency. Table 3 shows the results of the estimation of the measurement model. This process essentially involves three stages (see e.g. Roldán and Sánchez-Franco, 2012). First, the reliability of the individual indicators is evaluated using their factor loadings ( $\lambda$ ). This permits an evaluation of whether or not each indicator that forms the construct is highly correlated with its respective latent variable. Variables made up of just one item have a factor loading of 1 . The results show that all the values, except one, exceed the threshold of 0.7 required by Carmines and Zeller (1979). The only value that does not reach this value is CEO, included in the BDpolit construct. Nonetheless, the value is 0.69 , so it can be accepted as valid.

Second, reliability is explored analysing Cronbach's Alpha, for simple reliability, and the Composite Reliability (CR) value to measure composite reliability. Reliability indicates whether or not the set of variables is consistent in what it intends to measure. Table 3 shows the results of the estimation of the measurement model. For the Cronbach's Alpha value, 0.7 is usually considered the critical threshold. However, 
academic papers such as Malloy and Agarwall (2010) present values around 0.6. Moreover, the validity of the values must take into account the meaning of the items and whether they are capturing similar things. In our case, the two items that capture efficiency measures (DEA1 and DEA2), the politicisation of the board (CEO and POL) and the social responsibility orientation of the board (social expenses in 2009 and the profit of 2008 allocated to welfare issues) represent similar concepts. All Composite Reliability (CR) values exceeded the critical threshold of 0.7 for all variables.

[Insert Table 3 about here]

Third, validity is assessed by using convergent validity and discriminant validity. Convergent validity is analysed through average variance extracted (AVE) values and evaluates the degree to which the indicators reflect or represent the construct. Table 3 shows that all the AVE values are above 0.5, which guarantees convergent validity (Fornell and Larcker, 1981). Discriminant validity indicates whether each construct in the model is significantly different from the others. The most accepted method for PLS is the comparison of the square root of the AVE values and the correlation between variables (Barclay et al., 1995). Table 4 presents, on the diagonal, the square root of each construct's AVE values and, off the diagonal, the estimated correlations for each pair of constructs. Data in Table 4 confirms the existence of discriminant validity between the constructs since the square root of each AVE value is higher than the estimated correlations.

[Insert Table 4 about here] 


\subsection{Analysis of the structural model}

The analysis of the structural model enables us to test the proposed relationships. To assess the significance of the path coefficients, we used a bootstrapping procedure with 5,000 subsamples. This structural model is examined observing the $\mathrm{R}^{2}$ values of the dependent variables which present values exceeding the minimum threshold (0.1), with the model explaining $11 \%$ of the efficiency, $66 \%$ of the social responsibility and $46 \%$ of the profitability. To evaluate the predictive relevance of the model, we use the Stone-Geisser test, the $\mathrm{Q}^{2}$ values being positive for the three dependent variables $\left(\mathrm{Q}^{2}\right.$ Effic $=0.075 ; Q^{2}$-Profit $=0.4139 ; Q^{2}$-Social respons $\left.=0.484\right)$. Thus, it can be assumed that the dependent variables can be explained by the independent variables. The hypotheses can be supported or not through the interpretation of the structural path coefficients that are shown in Table 5.

The results of the structural model in Table 5 indicate that General Assembly characteristics did not affect performance. Therefore, we do not find support for Hypothesis 1, and our results suggest that this governing body had a representative role in SBs. The General Assembly had no significant influence on organisational goals. Neither its size, which could generate free-rider and coordination problems, nor its politicisation, which could promote a greater social orientation, influence organisational goals. This result suggests that the General Assembly had a representative role rather than a real influence on managerial decisions, which were taken by the boards of directors.

The politicisation of the board of directors had no significant influence on either efficiency or social responsibility (H2 is not supported). The sign of the coefficients obtained in the analysis of our structural model, suggests, as expected, that politicians had a negative effect on efficiency, but a positive one on social responsibility. 
Nonetheless, the small values of both coefficients and $t$ statistics ( $\mathrm{p}$ values) show that this relationship was far from being a key factor in organisational performance. It seems that politicians were not worried about legitimating their presence or about focusing on serving stakeholders' interests better.

Board size had a positive influence both on efficiency and on social responsibility, but the effect is significant only for social responsibility. Therefore, we find support for H3b. The stewardship orientation of the board and the search for legitimacy might explain this result, as we discuss in the following section. For H3a, the lack of significance of BDsize on efficiency suggests that core financial decisions were mainly taken by the professional managers of the boards. Stakeholder representatives were most likely focused on the social performance of SBs and, thus, more interested in the social dimension and less concerned about economic decisions. The legitimation of a larger board may be achieved by devoting resources to those issues more important for stakeholders, in this case social programs, rather than by taking decisions that affect the efficiency of the organisation.

Results indicate, in line with H4, that efficiency is related to profitability, at the $10 \%$ significant level. This relationship is positive, showing that a profit-oriented management resulted in higher profitability. However, the level of significance suggests, as argued in the development of this hypothesis, that the transference of efficiency to profitability is not direct. Finally, and in accordance with H5, resource allocation to social welfare programmes affected financial performance. This relationship is positive, that is, a greater allocation to social welfare programmes resulted in higher profitability. A greater social orientation of the boards increases profitability. This result is in line with Rodgers et al. (2013) and Saeidi et al. (2015), 
who state that a CSR orientation positively influences financial performance. The positive relationship of SR on profitability suggests that the clients of the SBs positively valued their social activities and that these strengthened customer loyalty towards their local SB. This, in turn, gave the SBs a competitive advantage in their main operating area, that is, their commercial activities. Loyalty resulted in a greater added value of commercial activities.

[Insert Table 5 about here]

\section{Discussion}

The lack of risk control, a basic element of management, led to the transformation and dismantling of many of the Spanish SBs, which were an important part of the Spanish banking system until the recent financial crisis. Some lessons can be extracted from the analysis of these organisations. Regarding corporate governance in non-profit entities, where there are no shareholders and ownership is vague, we have analysed the influence of the main governing bodies, the General Assembly and the Board of Directors, on two key organisational goals, economic and social performance. Neither the size of the General Assembly nor its politicisation influenced the goals of these entities. This indicates that the General Assembly was not relevant in decision-taking processes. Boards of directors were responsible for the operative decisions of the SBs. While some authors find that governmental influence on banking entities led to poor performance (Shleifer and Vishny, 1998; La Porta et al., 2002), our results do not suggest that political influence had a significant effect on the efficiency of SBs. The size of the board of SBs positively influenced social orientation, that is, the bigger the board, the higher the amount allocated to social welfare. This result is consistent with those 
obtained by Kassinis and Vafeas (2002), De Villiers et al. (2011) and Bachiller et al. (2015), who find a positive and significant link between board size and CSR activities. A board that is too small may not have the necessary level of competence. Instead, larger boards have a positive influence on performance because they possess greater collective information. The significant (positive) influence of the size of the board on social performance supports the idea that the board acted as a steward of those who elected its members and that organisational legitimation was gained through social responsibility achievements. Board size did not influence the economic performance. This suggests that the main economic decisions were taken by the professional managers, which 'reduced' the members of the board involved in these decisions to a level at which coordination problems and free-rider presence did not arise. The level of politicisation of the board is found as a feature that had no significant influence on the economic and social performance dimensions of the SBs. Politicians most likely felt legitimated by being representatives of democratic governments or institutions.

Efficiency is directly related to profitability. This means that SBs which better managed their resources increased their profitability. As Reboredo (2004) and GarcíaCestona and Surroca (2008) conclude, the more efficient SBs obtain a better performance. The traditional business of the banking sector (granting credit and capturing deposits) guaranteed that SBs were profitable. An entity will be more profitable when the gap between intermediation margin and costs of its branches is bigger. SBs social orientation is positively related to profitability. With a greater social orientation, firms may be able to improve their image and reputation and convert them to higher firm value and better financial performance. Thus, boards focused on social activities can achieve better financial performance. This finding provides insightful 
knowledge for the Spanish restructured financial sector, for the financial sectors of other countries, and for other industries.

As a limitation of this study, we would like to highlight that this paper has not addressed the role of the main governing bodies of SBs in the monitoring and control of risks. The lack of risk control has been a major cause of the problems faced by the Spanish banking system. Poor corporate governance leads to bank failures and the possibility of broader macroeconomic implications (García-Meca and Sanchez-Ballesta, 2014).

\section{Conclusions}

We have investigated, using a structural equation model approach, the relationship between the main governing bodies and the economic and social performance of Spanish savings banks. We find that General Assembly characteristics did not affect SBs performance. The level of politicisation of the board had no significant influence on the economic and social performance dimensions of the SBs. Board size did affect social performance, but did not influence efficiency, most likely because greater stakeholder representativeness made them more oriented to social than to economic goals. Greater allocation to social welfare programmes resulted in higher profitability. Therefore, boards more focused on social responsibility are able of achieving better financial performance.

Spanish SBs failed because of the lack of risk control but, during many years, SBs were a significant part of the financial system and devoted thousands of millions of euros to social welfare programmes. Politicisation has been blamed as a source of lack of risk control; however, the stewardship orientation of these boards permitted them to have competitive advantages that were translated to profitability. Financial institutions 
should value the importance of CSR orientation to achieve a better economic performance. 


\section{References}

Adams, R. M. and Mehran, H. (2012). Bank board structure and performance: Evidence for large bank holding companies. Journal of Financial Intermediation, 21, 243267.

Akhavein, J. D., Berger, A. N. and Humphrey, D. B. (1997). The Effects of Megamergers on Efficiency and Prices: Evidence from a Bank Profit Function. SSRN Electronic Journal, 12, 95-139.

Altunbas, Y., Evans, L., and Molyneux, P. (2001). Bank ownership and efficiency. Journal of Money, Credit and Banking, 33(4), 926-954.

Bachiller, P., Giorgino, M. C., and Paternostro, S. (2015). Influence of board of directors on firm performance: Analysis of family and non-family firms. International Journal of Disclosure and Governance, 12(3), 230-253.

Bai, G. (2013). How Do Board Size and Occupational Background of Directors Influence Social Performance in For-profit and Non-profit Organizations? Evidence from California Hospitals. Journal of Business Ethics, 118, 171-187.

Banker, R.D. (1984). Estimating most Productive Scale Size using Data Envelopment Analysis", European Journal of Operational Research, 17(1), 35-44.

Barclay, D., Higgins, C. and Thompson, R. (1995). The partial least squares (PLS). approach to causal modeling: personal computer adoption and use as an illustration. Technology Studies, 2, 285-309.

Barth, J.R., G. Caprio, and R. Levine. (2004). Bank Regulation and Supervision: What Works Best?, Journal of Financial intermediation 13 (2): 205-48.

Behr, A. and Heid, F. (2011). The success of bank mergers revisited. An assessment based on a matching strategy. Journal of Empirical Finance, 18(1), 117-135.

Bennedsen, M., Christian, H.K. and Nielsen, K.M. (2008). The causal effect of board size in the performance of small and medium-sized firms. Journal of Banking and Finance, 32, 1098-1109.

Berger, A. N., and Mester, L. J. (1997). Inside the black box: What explains differences in the efficiencies of financial institutions? Journal of Banking and Finance, 21(7), 895-947.

Bozec, R. and Dia, M. (2007). Board structure and firm technical efficiency: Evidence from Canadian state-owned enterprises. European Journal of Operational Research 177(3), 1734-1750.

Brown, W.O., Helland, E. and Smith, J.K. (2006). Corporate philanthropic practices. Journal of Corporate Finance, 12, 855-877.

Caiazza, S., Clare, A. and Pozzolo, A. F. (2012). What do bank acquirers want? Evidence from worldwide bank M\&A targets. Journal of Banking \& Finance, 36(9), 2641-2659.

Carbo, S., E.P.M. Gardener, and J. Williams. (2003). A Note on Technical Change in Banking: the Case of European Savings Banks. Applied Economics, 35(6), 705-19. 
Carmines E, Zeller R (1979). Reliability and validity assessment. in Sage University Paper Series on Quantitative Applications in the Social Sciences 07-017 Sage: Beverly Hills.

CECA (2009): Anuario estadístico de las Cajas de Ahorro. Confederación Española de las Cajas de Ahorro. Madrid.

Charnes, A., W.W. Cooper, and E. Rhodes. (1978). Measuring Efficiency of DecisionMaking Units", European Journal of Operational Research, 2(6), 429-44.

Cheng, S. (2008). Board size and the variability of corporate performance. Journal of Financial Economics, 87, 157-176.

Cohen, J. (1988). Statistical Power Analysis for the Behavioral Sciences. Lawrence Erlbaum Associates, New Jersey.

Coles, J.L., Daniel, N. and Naveen, L. (2008). Boards: does one size fit all? Journal of Financial Economics 87(2), 329-356.

Crespí, R., M.A. García-Cestona, and Salas, V. (2004). Governance Mechanisms in Spanish Banks. Does ownership matter?. Journal of Banking and Finance 28 (10), 2311-30.

Cuadrado-Ballesteros, B., García Rubio, R. and Martínez Ferrero, J. (2015). Efecto de la composición del consejo de administración en las prácticas de responsabilidad social corporativa. Revista de Contabilidad - Spanish Accounting Review, 18(1), 20-31

Cuesta, R.A. and L. Orea (2002). Mergers and Technical Efficiency in Spanish Savings Banks: A Stochastic Distance Function Approach. Journal of Banking and Finance 26 (12), 2231-47.

Cuesta, R.A. and L. Zofío. (2005). Hyperbolic Efficiency and Parametric Distance Functions: with Application to Spanish Savings Banks, Journal of Productivity Analysis 24 (1), 31-48.

Cumberland, D. M., S. A. Kerrick, J. D'Mello and J. M. Petrosko. (2015). Nonprofit Board Balance and Perceived Performance. Nonprofit Management and Leadership, 25(4), 449-462.

Cuñat, V. y Garicano, L., (2010), ¿Concedieron las cajas buenas créditos malos? Gobierno corporativo, capital humano y carteras de créditos. En La crisis de la economía española. Análisis económico de la gran recesión. Fundación de Estudios de Economía Aplicada, 351-398.

De Andres, P., and Vallelado, E. (2008). Corporate governance in banking: The role of the board of directors. Journal of Banking and Finance, 32(12), 2570-2580.

De Andres, P., Azofra, V. and Lopez, F. (2005). Corporate boards in OECD countries: Size, composition, functioning and effectiveness. Corporate Governance: An International Review, 13(2), 197-210.

De Villiers C, Naiker V, Van Staden CJ (2011). The effect of board characteristics on firm environmental performance. Journal of Management, 37, 1636-1663. 
Delgado, J., V. Salas, and J. Saurina. (2007). Joint Size and Ownership Specialization in Bank Lending. Journal of Banking and Finance, 31(12), 3563-83.

Eisenberg, T., Sundgren, S., and Wells, M. T. (1998). Larger board size and decreasing firm value in small firms. Journal of Financial Economics, 48(1), 35-54.

Ellwood, S., and Garcia-Lacalle, J. (2015). The influence of presence and position of women on the boards of directors: the case of NHS foundation trusts. Journal of Business Ethics, 130(1), 69-84.

Fernández-Gago, R., Cabeza-García, L., and Nieto, M. (2016). Corporate social responsibility, board of directors, and firm performance: an analysis of their relationships. Review of Managerial Science, 10(1), 85-104.

Fonseca, A.R. (2005). El Gobierno de las Cajas de Ahorros: Influencia sobre la Eficiencia y el Riesgo [Goverment Ownership of Savings Banks: Effect on the Efficiency and the Risk-Taking Behavior], Universia Business Review, 8, 24-37.

Fornell, C. and Bookstein. F.L. (1982). Two Structural Equations Models: LISREL and PLS Applied to Customer Exit-Voice Theory. Journal of Marketing Research 19(4), 440-52.

Fornell C. and Larcker D. (1981). Evaluating structural equation models with unobservable variables and measurement error. Journal of Marketing Research, 18, $39-50$.

Garcia-Castro, R., Ariño, M.A. and canela, M.A. (2010) Does Social Performance Really Lead to Financial Performance? Accounting for Endogeneity. Journal of Business Ethics, 92 (1), 107-126

García-Cestona, M. and Surroca, J. (2008). Multiple Goals and Ownership Structure: Effects on the Performance of Spanish Savings Banks. European Journal of Operational Research, 187(2), 582-99.

García-Meca, E. (2015). Political connections, gender diversity and compensation policy. Review of Managerial Science, 10(3), 1-24.

García-Meca, E., and García-García, J. A. (2015). Experience, political connections and efficiency in the financial sector. Academia Revista Latinoamericana de Administración, 28(3), 380-395.

García-Meca, E., and Sánchez-Ballesta, J. P. (2014). Politicization, banking experience and risk in savings banks. European Journal of Law and Economics, 38(3), 535553.

Garcia-Torea, N., Fernandez-Feijoo, B., de la Cuesta, M. (2016) Board of director's effectiveness and the stakeholder perspective of corporate governance: Do effective boards promote the interests of shareholders and stakeholders? BRQ Business Research Quarterly, 19, 246-260.

Guest, P. M. (2009). The impact of board size on firm performance: evidence from the UK. The European Journal of Finance, 15(4), 385-404. 
Guthrie, J. and Parker, L.D., (1989). Corporate social reporting: a rebuttal of legitimacy theory. Accounting and Business Research. 19 (76), 343-352.

Hair, J. F., Sarstedt, M., Pieper, T.M. and Ringle C.M. (2012) The Use of Partial Least Squares Structural Equation Modeling in Strategic Management Research: A Review of Past Practices and Recommendations for Future Applications. Long Range Planning, 45, 320-340.

Hambrick, D.C. and Mason, P.A. (1984). Upper Echelons: The organization as a reflection of its top managers. Academy of Management Review, 9, 193-206.

Heemskerk, K., E. M. Heemskerk, and M. Wats. (2015). Behavioral Determinants of Nonprofit Board Performance. Nonprofit Management and Leadership, 25(4), 41730.

Illueca, M., J.M. Pastor, and E. Tortosa-Ausina. (2009). The Effects of Geographic Expansion on the Productivity of Spanish Savings Banks. Journal of Productivity Analysis, 32(2), 119-43.

Illueca, M., Norden, L., and Udell, G. F. (2013). Liberalization and Risk-Taking: Evidence from Government-Controlled Banks. Review of Finance, 52(7), 12171257.

Kassinis G, Vafeas M (2002). Boards and outside stakeholders as determinants of environmental litigation. Strategic Management Journal, 23, 399-415.

Kumbhakar, S.C., A. Lozano-Vivas, C.A.K. Lovell, and I. Hasan. (2001). The Effects of Deregulation on the Performance of Financial Institutions: The Case of Spanish Savings Banks. Journal of Money Credit and Banking, 33(1), 101-120.

Laguir, I., Stagliano, R. and Elbaz, J. (2015) Does corporate social responsibility affect corporate tax aggressiveness? Journal of Cleaner production 107, 662675.

La Porta, R., F. Lopez-de-Silanes and A. Shleifer. (2002). Government Ownership of Banks. Journal of Finance, 57(1), 265-301.

Lozano Vivas, A. (1997). Profit efficiency for Spanish savings banks. European Journal of Operational Research, 98(2), 381-394.

Malloy, D. C. and Agarwal, J. (2010). Ethical Climate in Government and Nonprofit Sectors: Public Policy Implications for Service Delivery. Journal of Business Ethics, 94(3), 3-21

Maroto Acín, J.A. and Melle Hernández, M. (1999). Una aplicación del gobierno de empresas: incidencia de las Administraciones Públicas en las decisiones asignativas de las Cajas de Ahorro españolas. Revista Europea de Dirección y Economía de la Empresa, 8(2), 9-40.

Maudos, J., Pastor J.M. and Perez F. (2002a). Competition and Efficiency in the Spanish Banking Sector: the Importance of Specialization. Applied Financial Economics, 12(7), 505-16. 
Maudos, J., Pastor, J. M., Perez, F., and Quesada, J. (2002b). Cost and profit efficiency in European banks. Journal of International Financial Markets, Institutions and Money, 12(1), 33-58.

Menozzi, A., Gutiérrez-Urtiaga, M. and Vannoni, D. (2012) Board composition, political connections, and performance in state-owned enterprises. Industrial and Corporate Change, 21(3), 671-698

Micco, A., Panizza, U., and Yanez, M. (2007). Bank ownership and performance. Does politics matter? Journal of Banking and Finance, 31(1), 219-241.

Parejo, J.A., García, A.C. and Gámir, J.A.P. (2014). Manual de Sistema Financiero Español, [Manual of the Spanish Financial System] Ariel.

Park, E., Kim, J.K and Kwon, S.J. (2017) Corporate social responsibility as a determinant of consumer loyalty: An examination of ethical standard, satisfaction, and trust. Journal of Business Research 76, 8-13.

Pastor, J.M., Pavia, J.M., Tortosa-Ausina, E., Serrano L. (2016): "Rich regions, poor regions and bank branch deregulation. Regional Studies, 1-17.

Pérez, S. G., Sánchez, C. B., and Martín, D. J. S. (2015). Politically connected firms in Spain. Business Research Quarterly, 18(4), 230-245.

Pina, V., Torres, L. and Bachiller, P. (2017). Mergers Between Savings Banks. The Solution for Improving Risk in the Spanish Banking Sector? International Review of Entrepreneurship, 15(1), 63-84.

Pina, V., Torres, L., and Bachiller, P. (2016). Political Influence and the Performance of Nonprofit Spanish Banks. Nonprofit Management and Leadership, 26(4), 471-488.

Prior, D. (2003). Long- and Short-Run Non-Parametric Cost Frontier Efficiency: An Application to Spanish Savings Banks, Journal of Banking and Finance, 27 (4), 655-71.

Reboredo, J. (2004). A Note on Efficiency and Solvency in Banking. Applied Economics Letters, 11(3), 183-85.

Rodgers, W., Choy, H. L., \& Guiral, A. (2013). Do investors value a firm's commitment to social activities? Journal of business ethics, 114(4), 607-623.

Roldán J, and Sánchez-Franco M (2012). Variance-based structural equation modeling: guidelines for using Partial Least Squares in information systems research. Research Methodologies, Innovations and Philosophies in Software Systems Engineering and Information Systems 193-221.

Saeidi, S.P., Sofian, S., Saeidi, P. Saeidi, S.P. and Saaeidi, S.A. (2015). How does corporate social responsibility contribute to firm financial performance? The mediating role of competitive advantage, reputation, and customer satisfaction. Journal of Business Research, 68(2), 341-350

Salas, V. and J. Saurina. (2003). Deregulation, Market Power and Risk Behaviour in Spanish Banks. European Economic Review, 47(6), 1061-075. 
San-Jose, L., Retolaza, J. L., and Pruñonosa, J. T. (2014). Efficiency in Spanish banking: A multistakeholder approach analysis. Journal of International Financial Markets, Institutions and Money, 32, 240-255.

Sapienza, P. (2002). The Effects of Banking Mergers on Loan Contracts. The Journal of Finance, 57(1), 329-367.

Sapienza, P. (2002). The effects of banking mergers on loan contracts. The Journal of Finance, 57(1), 329-367.

Sarsted, M., Ringle C. M., Smith, D., Reams R. and Hair J. F. (2014). Partial least squares structural equation modeling (PLS-SEM), A useful tool for family business researchers. Journal of Family Business Strategy, 5, 105-115

Serrano-Cinca, C., Fuertes-Callén, Y., and Gutiérrez-Nieto, B. (2007). Online reporting by banks: a structural modelling approach. Online Information Review, 31(3), 310332.

Shaukat, A., Qiu, Y. and Trojanowski G. (2016). Board Attributes, Corporate Social Responsibility Strategy, and Corporate Environmental and Social Performance. Journal of Business Ethics, 135(3), 569-585.

Shleifer, A. and R.W. Vishny. (1994). Politicians and Firms. Quarterly Journal of Economics, 109(4), 995-1025.

Shleifer, A. and Vishny, R.W. (1998). The grabbing hand: Government pathologies and their cures, Harvard University Press.

Schuman, M.C. (1995). Managing legitimacy: strategic and institutional approaches. Academy of Management Review 20 (3), 571-606.

Surroca, J., Tribo, J.A. and Waddock, S., (2004). Corporate responsibility and financial performance: the role of intangible resources. Strategic Management Journal, 31(5), 463-490.

Tortosa-Ausina, E., E. Grifell-Tatje, C. Armero and D. Conesa. (2008). Sensitivity Analysis of Efficiency and Malmquist Productivity Indices: An Application to Spanish Savings Banks. European Journal of Operational Research, 184 (3), 1062108

Trujillo-Ponce, A. (2013). What determines the profitability of banks? Evidence from Spain. Accounting \& Finance, 53(2), 561-586.

Vallascas, F. and Hagendorff, J. (2011). The impact of European bank mergers on bidder default risk. Journal of Banking \& Finance, 35(4), 902-915.

Vander Vennet, R. (1996). The effect of mergers and acquisitions on the efficiency and profitability of EC credit institutions. Journal of Banking and Finance, 20(9), 15311558.

Vander-Vennet, R. (1996). The effect of mergers and acquisitions on the efficiency and profitability of EC credit institutions. Journal of Banking \& Finance, 20(9), 15311558. 
Wang, D. T-H, Chen, P-H, Yu, T. H.-K. and Hsiao, C-Y (2015) The effects of corporate social responsibility on brand equity and firm performance. Journal of Business Research, 68, 2232-2236.

Williams, J., N. Peypoch, and C. P. Barros, (2011). The Luenberger indicator and productivity growth: A note on the European Savings Banks sector. Applied Economics, 43 (6), 747-55.

Yermarck, D. (1996): Higher market valuation of companies with a small board of directors. Journal of Financial Economics, 40, 185-213.

Ysa, T., Giné, M., Esteve, M., and Sierra, V. (2012). Public corporate governance of state-owned enterprises: evidence from the Spanish banking industry. Public Money and Management, 32(4), 265-272. 
Figure 1. Model of the relationships (hypotheses) studied

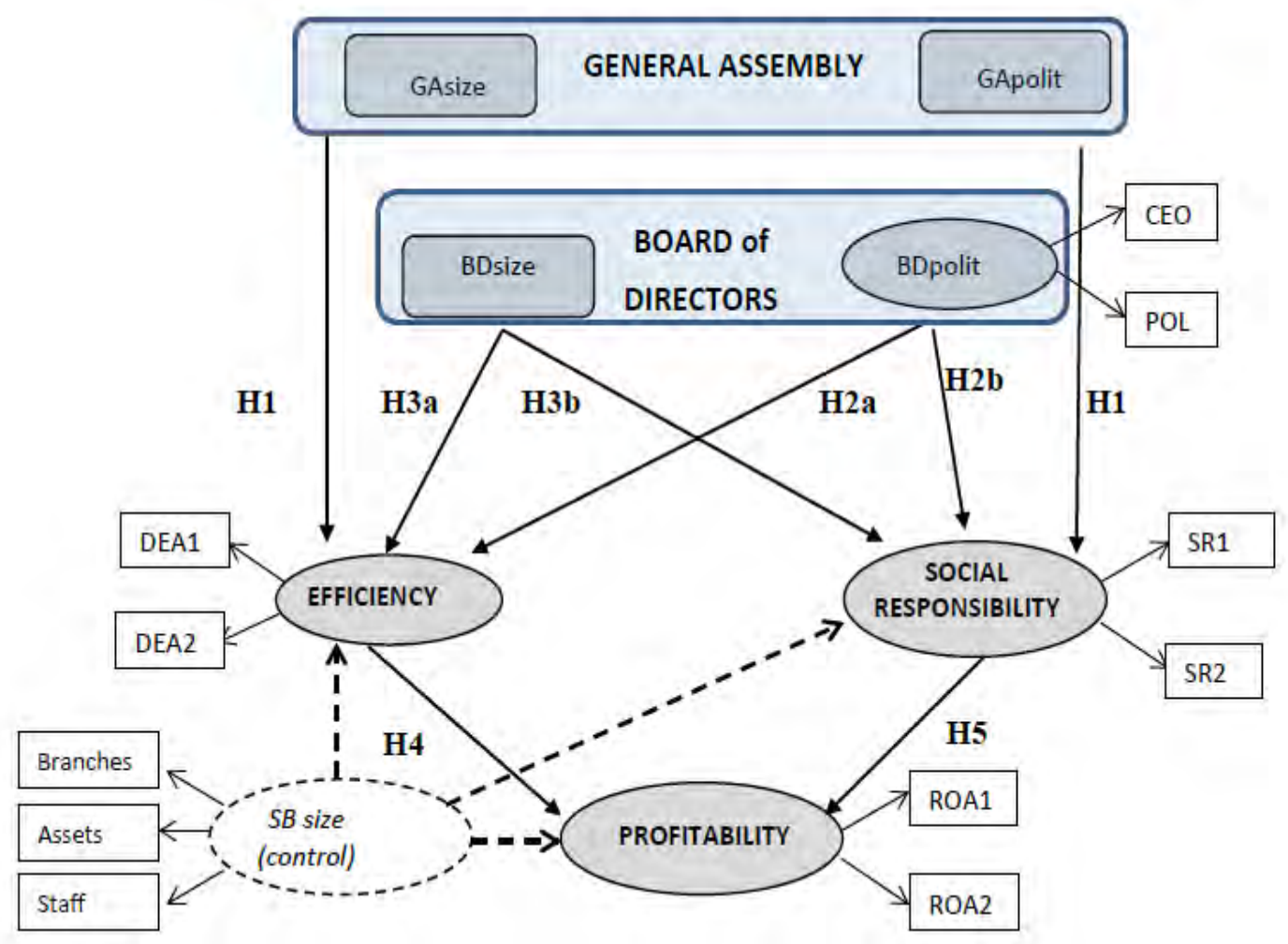

Note: Circular variables represent "constructs" while squares represent variables made up of a single item. 
Table 1 Independent and dependent variables included in the model.

\begin{tabular}{|c|c|c|}
\hline Variable & Item & Definition \\
\hline GApolit & GApolit & Percentage of institutional representatives on the Assembly \\
\hline GAsize & GAsize & Number of members of the Assembly \\
\hline \multirow{2}{*}{ BDpolit } & CEO & Dummy variable. '1' if CEO political background; \\
\hline & POL & Percentage of institutional representatives on the Board \\
\hline BDsize & BDsize & Number of members of the Board of Directors \\
\hline \multirow{2}{*}{ Efficiency } & DEA1 & DEA using the intermediation approach \\
\hline & DEA2 & DEA using the production approach \\
\hline $\begin{array}{l}\text { Social } \\
\text { Responsibility }\end{array}$ & $\begin{array}{l}\text { SR1 } \\
\text { SR2 }\end{array}$ & $\begin{array}{l}\text { Euros devoted to social welfare in } 2009(\ln ) \\
\text { Allocation of the profits of } 2008 \text { approved to social welfare } \\
(\ln )\end{array}$ \\
\hline \multirow{2}{*}{ Profitability } & ROA1 & Profit before Tax/Assets for 2009 \\
\hline & ROA2 & Net Profit/Assets for 2009 \\
\hline \multirow{3}{*}{ Size } & Branches & Number of branches $(\ln )$ \\
\hline & Assets & Total assets employed (ln) \\
\hline & Staff & Number of employees $(\ln )$ \\
\hline
\end{tabular}


Table 2. The descriptive statistics of the variables included in the analysis $(\mathrm{N}=45)^{1}$

\begin{tabular}{|c|c|c|c|c|c|}
\hline Item & Definition & Mean & Standard deviation & Maximun & Minimum \\
\hline GApolit (\%) & $\begin{array}{l}\text { Percentage of members of the General Assembly } \\
\text { with a connection in politics }\end{array}$ & 34.32 & 10.70 & 50 & 16.07 \\
\hline GAsize & $\begin{array}{l}\text { Total number of members of the General } \\
\text { Assembly }\end{array}$ & 131 & 52.96 & 320 & 30 \\
\hline CEO & $\begin{array}{l}\text { Dummy variable (value } 1, \text { CEO with a connection } \\
\text { in politics; otherwise } 0 \text { ) }\end{array}$ & & & $1(19 / 45)$ & $0(26 / 45)$ \\
\hline POL $(\%)$ & $\begin{array}{l}\text { Percentage of members of the board representing } \\
\text { regional and local governments }\end{array}$ & 36.07 & 19.20 & 73.68 & 5.26 \\
\hline BDsize & Total number of members of the board & 18 & 3.68 & 31 & 8 \\
\hline DEA1 & $\begin{array}{l}\text { Score obtained from DEA model whose inputs are } \\
\text { deposits, interest/charges paid and cost of staff } \\
\text { and whose outputs are credits and interest/fees } \\
\text { received }\end{array}$ & 0.93 & 0.07 & 1 & 0.8 \\
\hline DEA2 & $\begin{array}{l}\text { Score obtained from DEA model whose inputs are } \\
\text { branches and staff and whose outputs are deposits } \\
\text { and credits }\end{array}$ & 0.81 & 0.14 & 1 & 0.5 \\
\hline SR1 & Euros devoted to social welfare in 2009 (in 000) & 38,943 & 71,119 & 444,375 & 350 \\
\hline SR2 & $\begin{array}{l}\text { Allocation of the profits of } 2008 \text { approved to } \\
\text { social welfare (in €000) }\end{array}$ & 35,421 & 77,052 & 500,000 & 0 \\
\hline ROA1 (\%) & Return on Assets - Profit before Tax/Assets & 0.21 & 0.77 & 1.13 & -3.26 \\
\hline ROA2 (\%) & Return on Assets - Profit after Tax/Assets & 0.20 & 0.69 & 1.08 & -3.30 \\
\hline Branches & Total number of branches & 539 & 820.43 & 5,318 & 21 \\
\hline Assets & Total assets (in €000)) & 27,969 & 46,515 & 252,759 & 344,442 \\
\hline Staff & Total number of employees & 2,920 & $4,218.98$ & 25,689 & 87 \\
\hline
\end{tabular}

\footnotetext{
${ }^{1}$ For some variables, Caja Castilla La Mancha did not disclose financial data and has not been considered when data was not available.
} 
Table 3. Measurement model

\begin{tabular}{|c|c|c|c|c|c|c|}
\hline FACTOR & Indicator & $\begin{array}{l}\text { Cross- } \\
\text { loading }\end{array}$ & Alpha & \begin{tabular}{|c|} 
Composite \\
Reliability \\
Index \\
(CRI) \\
\end{tabular} & $\begin{array}{c}\text { Average } \\
\text { Variance } \\
\text { Extracted } \\
(\mathrm{AVE}) \\
\end{array}$ & $\mathbf{R}^{2}$ \\
\hline GApolit & GApolit & 1 & 1 & 1 & 1 & \\
\hline GAsize & GAsize & 1 & 1 & 1 & 1 & \\
\hline BDpolit & $\begin{array}{l}\text { CEO } \\
\text { POL }\end{array}$ & $\begin{array}{l}0.626 \\
0.981\end{array}$ & 0.633 & 0.800 & 0.677 & \\
\hline BDsize & BDsize & 1 & 1 & 1 & 1 & \\
\hline Effic & $\begin{array}{l}\text { DEA1 } \\
\text { DEA2 }\end{array}$ & $\begin{array}{l}0.923 \\
0.731\end{array}$ & 0.582 & 0.816 & 0.692 & 0.115 \\
\hline Social respons & $\begin{array}{l}\text { SR1 } \\
\text { SR2 }\end{array}$ & $\begin{array}{l}0.808 \\
0.918 \\
\end{array}$ & 0.673 & 0.855 & 0.747 & 0.655 \\
\hline Profit & $\begin{array}{l}\text { ROA1 } \\
\text { ROA2 }\end{array}$ & $\begin{array}{l}0.994 \\
0.992\end{array}$ & 0.986 & 0.993 & 0.986 & 0.461 \\
\hline Size & $\begin{array}{l}\text { Branches } \\
\text { Assets } \\
\text { Staff }\end{array}$ & $\begin{array}{l}0.993 \\
0.989 \\
0.997 \\
\end{array}$ & 0.993 & 0.995 & 0.986 & \\
\hline
\end{tabular}


Table 4. Correlations to determine discriminant validity

\begin{tabular}{|lcccccccc|}
\hline & GApolit & GAsize & BDpolit & BDsize & Effic & Profit & Social Respons. & Size \\
GApolit & $\mathbf{1}$ & & & & & & & \\
GAsize & 0.146 & $\mathbf{1}$ & & & & & \\
BDpolit & 0.320 & 0.298 & $\mathbf{0 . 8 2 3}$ & & & & \\
BDsize & -0.136 & 0.701 & 0.274 & $\mathbf{1}$ & & & \\
Effic & 0.055 & 0.226 & 0.041 & 0.312 & $\mathbf{0 . 8 3 2}$ & & \\
Profit & -0.105 & -0.011 & -0.044 & 0.104 & 0.414 & $\mathbf{0 . 9 9 3}$ & \\
Social respons. & -0.069 & 0.465 & 0.121 & 0.547 & 0.366 & 0.351 & $\mathbf{0 . 8 6 4}$ & \\
Size & -0.069 & 0.573 & 0.076 & 0.528 & 0.174 & -0.058 & 0.789 & $\mathbf{0 . 9 9 3}$ \\
\multicolumn{7}{c}{ Note: Figures on the diagonal (bold) are the square root of the AVE values. Off-diagonal figures are the construct } \\
\multicolumn{7}{c}{ correlations. }
\end{tabular}


Table 5. Results of the structural model

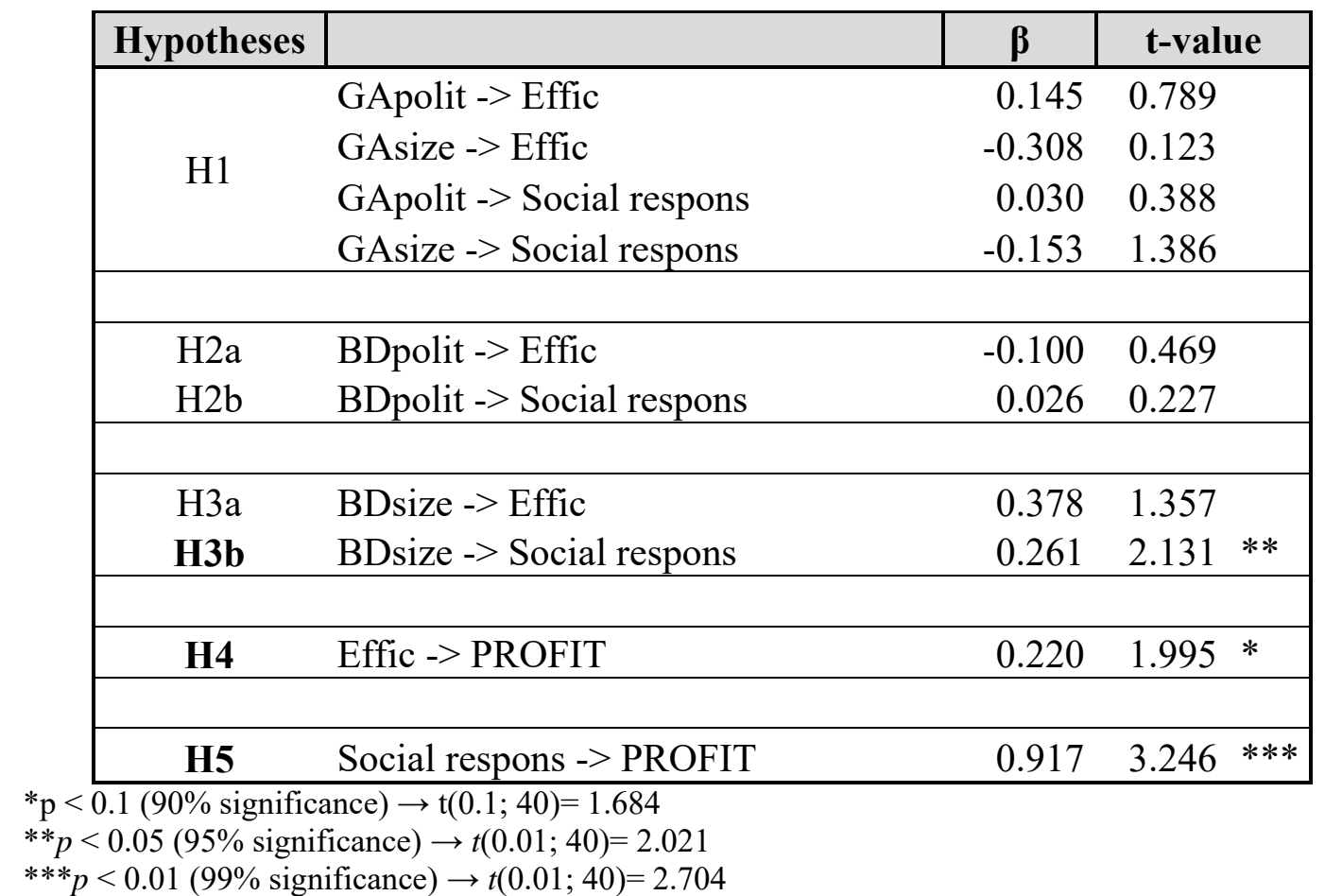

In bold. Hypotheses accepted.

The results for the control variable, size, are not presented, but it shows a negative and significant influence on profitability and a positive and significant influence on social responsibility. No significant influence of size on efficiency is found. 